\title{
Metode Pelatihan dan Persistensi Berpengaruh terhadap Kompetensi Pedagogik Guru PAUD
}

\author{
Aris Ciptaningtyas $\mathrm{K}^{\varpi_{1}}$, Elindra Yetti ${ }^{2}$, Sofia Hartati ${ }^{3}$ \\ Pendidikan Anak Usia Dini, Universitas Negeri Jakarta \\ DOI: $\underline{10.31004 / \text { obsesi.v4i2.440 }}$
}

\begin{abstract}
Abstrak
Penelitian ini bertujuan untuk mengetahui pengaruh antara metode pelatihan dan persistensi terhadap kompetensi pedagogik guru pendidikan anak usia dini. Penelitian ini merupakan penelitian kuantitatif, metode yang digunakan adalah expost facto. Desain yang digunakan dalam penelitian ini adalah desain factorial 2x2 (desain noneksperimental). Sampel penelitian ini adalah guru pendidikan anak usia dini yang pernah mengikuti pelatihan/diklat berjenjang tingkat dasar di wilayah Jakarta Timur. Pengumpulan data yang digunakan adalah teknik non tes dengan instrumen berupa angket/kuisioner. Data yang diperoleh dianalisis dengan menggunakan ANAVA dua jalur dan uji tuckey. Hasil penelitian mengungkapkan terdapat perbedaan yang signifikan antara rata-rata skor kompetensi pedagogik guru pendidikan anak usia dini yang mengikuti metode pelatihan dalam jaringan (daring/online) dan rata-rata skor kompetensi pedagogik guru pendidikan anak usia dini yang mengikuti metode pelatihan tatap muka, serta terdapat pengaruh interaksi antara metode pelatihan dan persistensi terhadap skor kompetensi pedagogik guru pendidikan anak usia dini.
\end{abstract}

Kata Kunci: metode pelatihan; persistensi; kompetensi pedagogik.

\begin{abstract}
This study aims to determine the effect of training methods and persistence on pedagogical competence of early childhood education teachers. This research is a quantitative study, the method used is ex post facto. The design used in this study is a $2 \times 2$ factorial design (nonexperimental design). The sample of this study is early childhood education teachers who have attended basic level of training in the East Jakarta area. Data collection used was a nontest technique with an instrument in the form of a questionnaire / questionnaire. The data obtained were analyzed using two-way ANAVA and tuckey test. The results revealed a significant difference between the average pedagogical competency scores of early childhood education teachers who took online training methods and the average pedagogical competency scores of early childhood education teachers who took face-to-face training methods, and there is an influence of interaction between training methods and persistence on pedagogical competency scores of early childhood education teachers.
\end{abstract}

Keywords: training methods; persistence; pedagogical competence.

Copyright (c) 2020 Aris Ciptaningtyas K, Elindra Yetti, Sofia Hartati

$\triangle$ Corresponding author :

Email Address : arisciptaningtyas_paud15s2@mahasiswa.unj.ac.id (Jakarta, Indonesia)

Received 19 January 2020, Accepted 22 January 2020, Published 23 January 2020 


\section{PENDAHULUAN}

Kompetensi pedagogik guru merupakan seperangkat pengetahuan, sikap dan keterampilan yang dimiliki seorang guru untuk berfikir dan bertindak dalam mengelola pembelajaran peserta didik mulai dari perencanaan hingga evaluasi dan penilaian untuk mencapai tujuan pembelajaran. Guru memegang peranan yang sangat penting dalam peningkatan mutu pendidikan. Untuk menjalankan perannya tersebut guru harus memiliki kemampuan. Sebagai faktor penentu bagi keberhasilan pendidikan di sekolah, guru merupakan sentral serta sumber kegiatan belajar mengajar. Lebih lanjut dinyatakan bahwa guru merupakan komponen yang berpengaruh dalam peningkatan mutu pendidikan di sekolah.

Pendapat Karin Apelgren dan Thomas Olsson tentang kompetensi pedagogik adalah kemampuan dan kemauan yang dilakukan secara teratur untuk menerapkan sikap, pengetahuan dan keterampilan yang dilakukan oleh guru dalam mengelola pembelajaran kepada peserta didiknya. Kompetensi pedagogik harus bisa dikembangkan sendiri oleh guru secara berkelanjutan untuk mencapai tujuan pembelajaran yang optimal. Adapun aspek dari kompetensi pedagogik yang harus dimiliki guru diantaranya adalah 1) sikap (attitude), 2) pengetahuan (knowledge), 3) kemampuan (ability), 4) mampu beradaptasi dengan situasi (adapting to the situation), 5) ketekunan (perserverence), 6) pengembangan berkelanjutan (continuous development), dan 7) integrasi dari keenam aspek yang ada (an integrated whole) (Apelgren \& Giertz, 2010).

Pendapat lain disampaikan Andreia dan Liliana yang mengatakan kompetensi pedagogik adalah kemampuan yang dimiliki seorang guru agar bisa mengkoordinasikan serta mengkombinasikan antara sumber-sumber pembelajaran yang terlihat seperti dari buku-buku, makalah, adanya kasus-kasus atau permasalahan serta pemanfaatan teknologi seperti penggunaan software dan hardware maupun dengan sumber pembelajaran yang tidak terlihat misalnya pengetahuan, keterampilan dan pengalaman dengan tujuan mencapai efektifiktas dan efisiensi dari sebuah proses pendidikan (Suciu \& Mata, 2011). Selain itu kompetensi pedagogik mengarah pada kualitas pengajaran. Dimana cakupan, kedalaman dan keluasan menjadi penting seperti halnya dalam merecanakan, menginisiasi, mengarahkan suatu program pendidikan.

Adapun pendapat dari Sonia Guerriero mengatakan kompetensi pedagogik guru adalah semua perilaku dari pengetahuan kognitif yang dimiliki seseorang untuk mengembangkan dan menciptakan lingkungan belajar dan mengajar yang efektif. Secara umum komponen dari kompetensi pedagogik yang harus dimiliki diantaranya: 1) pengetahuan tentang manajeman kelas, 2) pengetahuan tentang metode pengajaran, 3) pengetahuan tentang penilaian kelas, 4) pengetahuan terkait dengan struktur, dan 5) kemampuan untuk beradaptasi dengan lingkungan sekitar (Guerriero, 2013).

Penelitian dari Violeta dan Aneta Barakoska menyampaikan bahwa kompetensi pedagogik adalah kemampuan guru yang tidak hanya menyampaikan pengetahuan yang dimiliki kepada peserta didiknya, akan tetapi juga harus bisa mengembangkan pengetahuannya mengikuti perkembangan dan kecepatan zaman (Panev \& Barakoska, 2015). Oleh sebab itu sebagai guru yang professional harus mengetahui apa tujuan dari kegiatan pembelajaran yang dilakukan. Dengan demikian guru bisa meningkatkan kemampuan pedagogiknya setelah mengikuti berbagai aktivitas pengembangan.

Penelitian lainnya dari Rina Febriana menyampaikan terkait kompetensi pedagogik yang merupakan kemampuan guru dalam pengelolaan pembelajaran peserta didik yang sekurang-kurangnya meliputi hal-hal sebagai berikut: a) Memiliki pemahaman terhadap peserta didik. Artinya seorang guru harus bisa menguasai karakteristik peserta didik baik aspek fisik, moral, sosial, kultural, emoasinal, dan intelektual. b) Memiliki pemahaman wawasan kependidikan. Dengan demikian seorang guru harus menguasai teori belajar dan prinsip-prinsip pembelajaran yang mendidik. c) Mengembangkan kurikulum yang berkaitan dengan bidang pengembangan yang diampu. d) Merancang dan menyelenggarakan 
kegiatan pengembangan pembelajaran yang mendidik. e) Memanfaatkan teknologi informasi dan komunikasi untuk kepentingan penyelenggaraan kegiatan pengembangan yang mendidik. f) Memfasilitasi pengembangan potensi peserta didik untuk mengaktualisasikan berbagai potensi yang dimiliki. g) Berkomunikasi secara efektif, empatik dan santun dengan peserta didik. h) Menyelenggarakan penilaian dan evaluasi proses dan hasil belajar. i) Memanfaatkan hasil penilaian dan evaluasi untuk kepentingan pembelajaran. j) Melakukan tindakan reflektif untuk peningkatan kualitas pembelajaran. Jadi, harapannya guru dapat memiliki kompetensi pedagogik yang baik sehingga dapat menyusun rancangan pembelajaran dan melaksanakannya (Febriana, 2016). Dengan kemampuan pedagogik yang dimiliki guru PAUD, hasil penelitian Helly Apriyanti menyatakan bahwa guru PAUD ratarata telah memiliki pemahaman terhadap perencanaan pembelajaran tematik (Apriyanti, 2017).

Tribagus Kuncoro dkk, menyampaikan pendapatnya terkait kompetensi pedagogik guru merupakan kemampuan kognitif dalam melaksanakan proses-proses pembelajaran dan pengelolaan peserta didik yang sekurang-kurangnya adalah guru memiliki keterampilan dasar mengajar serta mampu memanfaatkan atau menggunakan teknologi pembelajaran (Sakti, Hairunisya, \& Sujai, 2019).

Sebagai garda terdepan dalam dunia pendidikan, guru harus mau meng-up grade kompetensi yang dimiliki dalam menghadapi era pendidikan yang memanfaatkan TIK dalam pembelajarannya. Guru dapat mengikuti berbagai macam pendidikan dan pelatihan serta harus terus belajar untuk meningkatkan kompetensi sehingga mampu menghadapi peserta didik generasi milenial. Menghadapi tantangan yang besar saat ini maka pendidikan dituntut untuk berubah juga diantaranya dengan adanya guru-guru yang profesional, guru yang mampu menguasai dan memanfaatkan teknologi informasi yang supercepat untuk meningkatkan kualitas proses belajar mengajar pada setiap satuan pendidikan dalam rangka mempersiapkan sumber daya manusia (SDM) yang unggul dengan kompetensi global. Hal ini sejalan dengan pendapat Zakiya yang menyebutkan hasil penelitiannya bahwa dengan mengikuti pendidikan dan latihan Pengembangan Keprofesian Berkelanjutan (PKB), guru dapat memperbaiki nilai uji kompetensi guru (UKG) yang belum memenuhi kompetensi capaian minimal (Maiza \& Nurhafizah, 2019). Dengan demikian dapat dikatakan bahwa untuk terus mengembangkan kompetensinya guru dapat mengikuti berbagai kegiatan pendidikan dan pelatihan (diklat) untuk menjadi guru yang lebih profesioanl.

Kegiatan pendidikan dan pelatihan yang dilaksanakan merupakan aktivitas belajar mengajar dalam sebuah wadah pelatihan yang mengacu kepada interaksi instruktur dan peserta pelatihan yang saling terpadu. Kegiatan pelatihan akan mencapai sebuah keterpaduan apabila antara instruktur dan peserta pelatihan dapat menjalankan tugas dan fungsinya dengan baik. Instruktur harus mampu mengelola, membimbing, mengarahkan dan memfasilitasi peserta pelatihan dengan memperhatikan berbagai aspek. Sedangkan peserta pelatihan harus bisa menerima arahan dan aktif dalam belajar. Keduanya secara beriringan mengarah kepada satu tujuan yang sama yakni tujuan pelatihan.

Adapun tujuan pelatihan ialah mencetak peserta pelatihan yang tidak hanya cerdas, tetapi juga kreatif, kritis, inovatif dan produktif sehingga mampu menghadapi persaingan global. Peserta pelatihan yang lahir dari pelatihan nasional diharapkan memiliki kecakapankecakapan sesuai dengan bakat dan minatnya masing-masing. Karena kecakapan hidup pada era globalisasi tidak lagi dipandang dari nilai akademik atau hasil belajarnya saja, tetapi juga dinilai dari bagaimana seseorang tersebut mampu bertahan dari masalahmasalah kehidupan yang akan datang. Pencapaian tujuan pelatihan bertombak pada bagaimana proses pelatihan berlangsung.

Program pelatihan yang direncanakan secara matang dan berkesinambungan dapat mendorong peningkatan mutu guru yang pada akhirnya akan berdampak pada peningkatan kualitas kinerja guru. Metode pelatihan berarti ketepatan cara penyampaian yang digunakan selama pelatihan itu berlangsung. Training yang tidak terlepas dari pengembangan 
kemampuan, pengukuran tujuan yang jelas, dan perubahan sikap dapat diterapkan dengan beberapa pilihan metode sesuai dengan lingkungan pelatihan. Beberapa metode tersebut meliputi lecture, guest facilitators, and video tape material.

Peneliti Dwi dan Istikomah mengatakan bahwa pendidikan dan pelatihan dalam suatu organisasi dimaksudkan sebagai sebuah proses usaha yang berhubungan dengan pemberian bantuan kepada seseorang yang bekerja di sebuah instansi atau organisasi agar dapat meningkatkan pengetahuan, kecerdasan dan kemampuannya di bidang tertentu (Arianto \& Istikomah, 2018). Adapun pelatihan untuk guru adalah sebuah proses meningkatkan kompetensi serta profesionalisme guru dalam melaksanakan tugas dan pekerjaannya sebagai seorang pendidik untuk meningkatkan mutu guru dan mutu pembelajaran. Adapun manfaat dari pelatihan bagi guru diantaranya adalah a) meningkatkan produktivitas organisasi secara menyeluruh, b) mewujudkan hubungan yang serasi antara atasan dan bawahan, c) proses pengambilan keputusan lebih cepat dan tepat, d) adanya dorongan pribadi untuk meningkatkan kompetensi, e) peningkatan kemampuan dapat mengatasi stress yang dihadapi, frustasi maupun konflik, f) meningkatkan kepuasan kerja, g) pengakuan atas kemampuan seseorang semakin besar, dan h) mengurangi ketakutan menghadapi tugas-tugas di masa depan. Sedangkan tujuan dari pelatihan diantaranya a) memberikan fasilitas kepada guru untuk meningkatkan kompetensi yang dimilikinya, b) memfasilitasi guru untuk belajar sesuai dengan perkembangan zaman, c) memotivasi guru untuk tetap memiliki komitmen dalam melaksanakan tugas pokoknya sebagai seorang pendidik, serta d) mengangkat citra, harkat dan martabat, rasa hormat dan kebanggaan menyandang profesi sebagai guru.

Dalam penelitiannya, Teresa dan Hery mengemukakan pendapat mereka terkait dengan pelatihan yaitu metode yang digunakan untuk memberikan pengetahuan bagi karyawan baru atau yang sudah ada dengan membekali keterampilan yang mereka butuhkan untuk melakukan pekerjaannya. Adapun metode pelatihan yang dapat dilakukan diantaranya : a) on the job training atau pelatihan langsung kerja, b) magang, c) belajar secara informal, d) job instruction training, e) pengajaran, f) palajaran yang terprogram, g) teknik pelatihan kemampuan membaca dan menulis, h) pelatihan dengan peralatan audiovisual, i) pelatihan dengan simulasi, $\mathrm{j}$ ) pelatihan berbasis computer, $\mathrm{k}$ ) system pendukung kinerja elektronik, l) pelatihan jarak jauh berbasis internet, $\mathrm{m}$ ) pelatihan melalui internet, n) rotasi pekerjaan, o) pendekatan belajar sambal dibimbing, dan p) belajar bertindak (Puteri \& $\mathrm{Tj}$, 2016).

Pelaksanaan metode pelatihan khususnya pelatihan guru PAUD yang dilaksanakan saat ini sangat beragam. Akan tetapi dalam usahanya meningkatkan kompetensi pendidik melalui pelatihan-pelatihan, di Indonesia masih terganjal banyak masalah jika dilakukan secara konvensional. Hal ini disebabkan banyaknya jumlah tenaga pendidik yang perlu mengikuti pelatihan-pelatihan tidak sebanding dengan banyaknya lembaga-lembaga penyelenggara pelatihan dan jumlah narasumber yang terbatas. Disamping itu juga keterbatasan waktu yang dimiliki pendidik untuk mengikuti pelatihan, karena tidak mudah bagi pendidik untuk meninggalkan kegiatan belajar mengajar di sekolah.

Program pelatihan untuk meningkatkan kompetensi guru dapat dilaksanakan secara tatap muka, dalam jaringan (daring) dan daring kombinasi yang pelaksanaannya dapat dilakukan di tingkat Kabupaten/Kota, Provinsi maupun nasional. Pelatihan dengan menggunakan metode tatap muka merupakan bagian dari sistem pembelajaran di mana terjadi interaksi secara langsung antara fasilitator dengan peserta pembelajaran. Interaksi pembelajaran yang terjadi dalam tatap muka meliputi pemberian input materi, tanya jawab, diskusi, latihan, kuis, praktik, dan penugasan.

Seiring dengan perkembangan ilmu pengetahuan dan teknologi informasi dan komunikasi itu sendiri, e-learning memiliki potensi yang cukup besar bagi dunia pendidikan jika dirancang dan diterapkan dengan sebaik-baiknya. E-learning pada dasarnya adalah suatu upaya yang memungkinkan suatu peristiwa belajar terjadi secara optimal dengan 
menerapkan teknologi informasi dan komunikasi secara tepat guna. Hal inilah yang menjadi tantangan besar penerapan e-learning. Tantangan penerapan e-learning, bukan pada teknologinya saja, tapi justru yang paling utama adalah terletak pada bagaimana upaya merancang (design) pembelajaran itu sendiri.

Sejalan dengan penelitian Irma Marciana dkk menyatakan bahwa salah satu bentuk peneraran e-learning adalah penggunaan metode dalam jaringan saat kegiatan pembelajaran (Rumengan, Lumenta, \& Paturusi, 2019). Adapun pelatihan dengan metode dalam jejaring/jaringan (Daring) adalah program guru pembelajar yang dilaksanakan dengan memanfaatkan teknologi jaringan komputer dan internet. Kegiatan pelatihan daring merupakan implementasi dari pendidikan jarak jauh yang bertujuan untuk pemerataan akses terhadap pembelajaran yang bermutu.

Pelatihan daring dapat dilaksanakan dengan mempersiapkan sistem pembelajaran yang secara mandiri memberikan instruksi dan layanan pembelajaran kepada peserta tanpa melibatkan secara langsung para pengampu dalam proses penyelenggaraannya. Sistem instruksional yang dimaksud meliputi proses registrasi, pelaksanaan pembelajaran, penilaian diri, tes sesi, dan penentuan kelulusan peserta berdasarkan nilai yang telah diakumulasikan dengan nilai tes akhir yang dilakukan di sistem serta penerbitan sertifikat.

Yusuf \& M. Nur menjelaskan pembelajaran daring adalah pembelajaran yang diselenggarakan melalui jejaring web dan jumlah partisipan yang tidak terbatas. Setiap mata kuliah/pelajaran menyediakan materi dalam bentuk rekaman video atau slideshow, dengan tugas-tugas mingguan yang harus dikerjakan dengan batas waktu pengerjaan yang telah ditentukan dan beragam sistem penilaian. Sistem pembelajaran daring bersifat terbuka dalam artian terbuka aksesnya bagi kalangan pendidikan, kalangan industri, kalangan usaha, dan khalayak masyarakat umum. Dengan sifat terbuka, tidak ada syarat pendaftaran khusus bagi pesertanya. Siapa saja, dengan latar belakang apa saja dan pada usia berapa saja, bisa mendaftar. Hak belajar tak mengenal latar belakang dan batas usia (Bilfaqih \& Qomarudin, 2015).

Indonesia dapat merumuskan alasan dibutuhkannya pembelajaran daring diantaranya disebabkan karena: a) Kapasitas pendidikan di Indonesia, baik pendidikan dasar dan menengah, pendidikan tinggi, maupun lembaga-lembaga workshop \& pelatihan masih sangat terbatas; b) Sebaran yang kurang merata sehingga meningkatkan biaya pendidikan/ pelatihan dan akomodasinya; c) Kebanyakan satuan pendidikan belum memiliki sumber daya pendidikan yang memadai dan berkualitas. Sekolah, perguruan tinggi dan lembaga pelatihan yang bermutu lebih terkonsentrasi di Pulau Jawa; d) Belum dapat mewujudkan layanan pendidikan dan pelatihan yang setara dan bermutu; dan e) Belum dapat menjamin pemenuhan kebutuhan dan permintaan pendidikan dan pelatihan yang bermutu.

Dengan berjalannya waktu, kegiatan diklat berjenjang bagi guru PAUD di Indonesia mengalami penyesuaian pelaksanaannya yaitu dengan metode daring yang diharapkan setiap peserta diklat memiliki kemampuan dasar teknologi informasi dan komunikasi (TIK) yaitu dalam mengoperasikan komputer dan telepon pintar (ponsel/HP) serta dapat mengakses internet. Adapun tujuan kegiatan diklat berjenjang tingkat dasar ini adalah untuk mempersiapkan pendidik agar lebih professional dalam menjalankan tugas mulai dari merencanakan, melaksanakan pembelajaran serta menilai hasil pembelajaran dan melakukan pembimbingan, pelatihan, pengasuhan dan perlindungan anak usia dini. Selain itu mempersiapkan pendidik agar memiliki kompetensi kepribadian, professional pedagogik, dan sosial.

Peserta kegiatan diklat pendamping muda atau diklat berjenjang tingkat dasar secara umum diutamakan bagi guru PAUD yang memiliki pendidikan SLTA atau memiliki pendidikan S1 selain PAUD/Psikologi dan yang sederajat, memiliki pengalaman bekerja di satuan PAUD minimal 1 (satu) tahun, belum pernah mengikuti diklat PAUD berjenjang, 
sehat jasmani dan rohani, bersedia mengikuti kegiatan diklat dari awal sampai dengan akhir, dan untuk peserta diklat dasar.

Struktur kurikulum atau materi yang disampaikan dalam diklat konvensional (tatap muka) maupun secara dalam jaringan (daring) dibedakan berdasarkan metode pelaksanaan kegiatan pelatihan. Pelaksanaan kegiatan diklat dasar guru PAUD mengacu pada pedoman diklat guru pendamping muda (diklat berjenjang tingkat dasar) dengan total beban waktu penyelenggaraan selama 258 jam pelajaran dengan rincian 48 jam pelajaran @ 45 menit secara tatap muka baik diklat secara konvensional maupun daring dan 210 jam pelajaran untuk pelaksanaan tugas mandiri. Berikut disajikan tabel perbandingan struktur materi dari metode pelatihan pelatihan tingkat dasar baik secara konvensional maupun daring.

Tabel 1. Perbandingan Struktur Materi Pelatihan Tingkat Dasar Secara Konvensional dan Daring

\begin{tabular}{|c|c|c|c|c|c|c|c|}
\hline \multirow{3}{*}{ No } & \multirow{3}{*}{ Materi } & \multicolumn{2}{|c|}{$\begin{array}{c}\text { Diklat } \\
\text { Konvensional } \\
\text { (Jam Pelajaran) }\end{array}$} & \multicolumn{4}{|c|}{ Diklat Daring (Jam Pelajaran) } \\
\hline & & \multirow{2}{*}{ Teori } & \multirow{2}{*}{ Praktek } & \multirow{2}{*}{$\begin{array}{l}\text { Tatap } \\
\text { Muka } \\
\text { Daring }\end{array}$} & \multirow{2}{*}{$\begin{array}{c}\text { Tutorial } \\
\text { Daring }\end{array}$} & \multicolumn{2}{|c|}{ Mandiri } \\
\hline & & & & & & Daring & Luring \\
\hline 1 & Kebijakan PAUD dan Dikmas & 2 & - & 2 & - & & \\
\hline \multicolumn{8}{|c|}{ Kegiatan Tatap Muka } \\
\hline 2 & Konsep Dasar PAUD & 2 & 2 & 2 & 2 & & \\
\hline 3 & Perkembangan Anak Usia Dini & 2 & 2 & 2 & 2 & & \\
\hline 4 & $\begin{array}{l}\text { Pengenalan Anak Berkebutuhan Khusus } \\
\text { (ABK) }\end{array}$ & 1 & 3 & 2 & 2 & & \\
\hline 5 & Cara Belajar Anak Usia Dini & 4 & 4 & 2 & 6 & & \\
\hline 6 & Perencanaan Pembelajaran & 1 & 2 & 2 & 4 & & \\
\hline 7 & Penilaian Perkembangan Anak & 1 & 2 & 2 & 3 & & \\
\hline 8 & Kesehatan dan Gizi Anak Usia Dini & 3 & 5 & 2 & 3 & & \\
\hline 9 & Komunikasi dalam Pengasuhan & 2 & 2 & 2 & 4 & & \\
\hline 10 & Etika Karakter Pendidik Anak Usia Dini & 2 & 2 & 2 & 1 & & \\
\hline 11 & $\begin{array}{l}\text { Praktek Pembelajaran dengan teman } \\
\text { sejawat }\end{array}$ & - & 4 & - & - & & \\
\hline \multicolumn{2}{|c|}{$\begin{array}{l}\text { Jumlah JP Tatap Muka (Tatap Muka } \\
\text { Konvensional dan Tatap Muka/Tutorial } \\
\text { Daring) }\end{array}$} & 20 & 28 & 21 & 27 & & \\
\hline \multicolumn{8}{|c|}{ Kegiatan Mandiri } \\
\hline 1 & $\begin{array}{l}\text { Pelaksanaan KBM “Belajar Melalui } \\
\text { Bermain" (Modul Cara Belajar AUD) }\end{array}$ & - & 50 & - & - & - & 40 \\
\hline 2 & $\begin{array}{l}\text { Penyusunan RPPH untuk } 5 \text { hari KBM } \\
\text { (Modul Perencanaan Pembelajaran) }\end{array}$ & - & 30 & - & - & 22 & 8 \\
\hline 3 & $\begin{array}{l}\text { Penilaian Perkembangan Anak dalam } \\
\text { KBM (Modul Evaluasi Pembelajaran) }\end{array}$ & - & - & - & - & - & 20 \\
\hline 4 & $\begin{array}{l}\text { Advokasi Dana Desa (Model Konsep } \\
\text { Dasar PAUD terkait Mutu Layanan } \\
\text { PAUD dan Peningkatan Kompetensi } \\
\text { Guru PAUD) }\end{array}$ & - & - & - & - & 8 & 22 \\
\hline 5 & $\begin{array}{l}\text { Kegiatan Pembiasaan Hidup Bersih dan } \\
\text { Sehat (Modul Kesehatan dan Gizi) }\end{array}$ & - & 40 & - & - & \multirow{3}{*}{8} & \multirow{3}{*}{12} \\
\hline 6 & $\begin{array}{l}\text { Identifikasi Perkembangan Anak } \\
\text { (Modul Perkembangan Anak dan } \\
\text { Modul Anak dengan Berkebutuhan } \\
\text { Khusus) }\end{array}$ & \multirow{2}{*}{ - } & \multirow{2}{*}{20} & \multirow{2}{*}{-} & \multirow{2}{*}{-} & & \\
\hline 7 & $\begin{array}{l}\text { Interaksi Positif Guru dengan Anak dan } \\
\text { Orangtua (Modul Komunikasi dalam } \\
\text { Pengasuhan serta Modul Etika dan } \\
\text { Karakter Pendidik AUD) }\end{array}$ & & & & & & \\
\hline & Kunjungan Belajar Lokal & - & 20 & & & & 20 \\
\hline
\end{tabular}




\begin{tabular}{|c|c|c|c|c|c|c|c|}
\hline \multirow{3}{*}{ No } & \multirow{3}{*}{ Materi } & \multicolumn{2}{|c|}{$\begin{array}{c}\text { Diklat } \\
\text { Konvensional } \\
\text { (Jam Pelajaran) }\end{array}$} & \multicolumn{4}{|c|}{ Diklat Daring (Jam Pelajaran) } \\
\hline & & \multirow[b]{2}{*}{ Teori } & \multirow[b]{2}{*}{ Praktek } & \multirow{2}{*}{$\begin{array}{c}\text { Tatap } \\
\text { Muka } \\
\text { Daring }\end{array}$} & \multirow{2}{*}{$\begin{array}{c}\text { Tutorial } \\
\text { Daring }\end{array}$} & \multicolumn{2}{|c|}{ Mandiri } \\
\hline & & & & & & Daring & Luring \\
\hline & Mengikuti Kegiatan Gugus PAUD & - & 20 & - & - & 20 & - \\
\hline & Penyusunan Laporan Tugas Mandiri & - & 30 & - & - & 22 & 8 \\
\hline \multicolumn{2}{|c|}{ Jumlah JP Kegiatan Mandiri } & - & 210 & - & - & 80 & 130 \\
\hline \multicolumn{2}{|c|}{ Jumlah JP Tatap Muka dan Tugas Mandiri } & 20 & 238 & 21 & 27 & 80 & 130 \\
\hline \multicolumn{2}{|c|}{ Total JP } & \multicolumn{2}{|c|}{258} & \multicolumn{4}{|c|}{258} \\
\hline
\end{tabular}

Sumber : (Dit.Bin. GTK PAUD dan Dikmas, 2018) dan (PP PAUD dan Dikmas, 2018)

Berdasarkan tabel tersebut dalam struktur materi pada diklat daring yang dimaksud dengan tatap muka daring ialah memberikan pemahaman kepada peserta terhadap materi yang disampaikan melalui fasilitas video conference oleh narasumber dan pengampu dengan 10 kali pertemuan yaitu 1 kali untuk materi kebijakan dan 9 kali untuk materi yang ada di pedoman Diklat. Sedangkan tutorial daring bertujuan untuk membimbing memecakan permasalahan atau kesulitan yang dihadapi peserta dalam memahami modul, mengerjakan tugas maupun menerapkan modul yang telah disampaikan dan kegiatan tutorial daring ini dilakukan melalui forum diskusi (whatsapp dan/atau email). Kegiatan mandiri dilakukan secara daring dan luring yang dilaksanakan dalam 25 hari kerja (210 JPL) dan akan difasilitasi oleh mentor untuk pembelajaran, admin daerah untuk administrasi dengan kegiatan yang harus diikuti mulai dari persiapan, praktik pembelajaran, evaluasi dan pelaporan.

Saat mengikuti pendidikan dan pelatihan dengan menggunakan berbagai metode, persistensi atau ketekunan harus dimiliki oleh setiap peserta kegiatan guna mendapatkan hasil yang maksimal. Persistensi sendiri berasal dari bagian elemen motivasi. Donovan dan Umar mendefinisikan bahwa motivasi adalah sekelompok pendorong yang mempuanyai ciri-ciri berasal dari dalam atau dari luar individu yang dapat menimbulkan perilaku bekerja, dapat menentukan bentuk, tujuan, intensitas dan ketekunan lamanya bekerja (Donovan \& Umar, 2010). Untuk meraih kesuksesan dalam mengerjakan suatu pekerjaan harus dimulai dari kemauan dalam diri sendiri serta didukung oleh lingkungan sekitar dan harus memiliki arah atau tujuan yang ingin dihasilkan dari pekerjaan yang dilakukannya dengan melihat intensitas atau waktu pelaksanaan kegiatan serta bagaimana ketekunan seseorang.

Persistensi merupakan salah satu kekuatan karakter yang dikemukakan oleh Seligman and Peterson, yang mendefinisikan persistensi sebagai kelanjutan dari tindakan sukarela yang dilakukan untuk mencapai suatu tujuan meskipun ada hambatan, kesulitan atau keputusasaan (Peterson \& Seligman, 2004). Hill dalam Adelia juga mengemukakan bahwa dasar dari persistensi adalah kekuatan kehendak (the power of will). Hal yang menjadi penghalang bagi individu bukanlah ketakutan melainkan kebosanan, frustasi, kesulitan dan godaan untuk melakukan sesuatu yang lebih mudah dan menyenangkan. Adapun beberapa faktor yang dapat mempengaruhi persistensi yaitu perilaku atas usaha yang dilakukan (effortful behavior), dukungan sosial dan umpan balik (feedback) (Zamista, 2018).

Menurut pendapat Colquitt, terdapat tiga unsur kunci dalam diri kita yang harusd dimiliki seseorang dalam meraih kesuksesan diantaranya intensitas, arah dan ketekunan (persistensi) (Colquitt, Lepine, \& Wesson, 2009). Dimana ketekunan terkait dengan seberapa keras usaha seseorang dalam berjuang. Oleh karena itu, kita harus mempertimbangkan ketekunan dengan kualitas upaya yang telah dilakukan. Upaya tersebut akan diarahkan ke sasaran dan konsisten seseorang dalam mengusahakan mendapatkan sesuatu.

Mencermati betapa pentingnya metode pelatihan serta persistensi guru dalam melaksanakan apa yang ditugaskan kepadanya untuk bisa meningkatkan mutu pendidikan dengan mengembangkan kompetensi pedagogik yang dimiliki, maka dilakukan observasi 
pendahuluan dan wawancara mengenai metode pelatihan serta persistensi guru PAUD khususnya di wilayah Jakarta Timur. Berdasarkan hasil observasi pada proses pelatihan untuk guru PAUD ditemui bahwa instruktur/narasumber masih cenderung menggunakan metode konvensional. Metode pelatihan kovensional mengakibatkan tidak ada interdependensi positif, pembagian kerja kelompok yang kurang efektif dikarenakan dalam kelompok terbiasa dengan hanya beberapa peserta yang bekerja dan kurang ada rangsangan bagi peserta pelatihan untuk meningkatkan kompetensi dengan memberikan kesempatan untuk berkreasi. Ketidaktahuan instruktur akan beragam metode yang dapat digunakan pada pelatihan kompetensi guru sehingga pelatihan lebih banyak berlangsung dari satu arah (teacher center). Serta masih kurangnya perhatian instruktur akan motivasi internal peserta pelatihan dalam belajar dan mengembangkan kreativitasnya sehingga persistensi dirasakan sangat rendah. Hasil dari mengikuti pelatihan cenderung hanya terlihat saat kegiatan berlangsung saja sebagai pemenuhan kewajiban tugas yang diberikan karena guru tidak bisa mempraktekkan langsung kepada peserta didiknya terkait materi apa yang telah dipelajarinya. Selain itu dengan mengikuti pelatihan secara konvensional, guru yang ditugaskan harus meninggalkan sekolah atau lembaganya dalam waktu yang ditentukan dan mengakibatkan kegiatan pembelajaran di sekolah menjadi kurang optimal karena guru yang tertinggal di sekolah memiliki pekerjaan tambahan mengajar peserta didik lainnya. Oleh sebab itu kegiatan pelatihan dirasakan hanya sebatas kegiatan saja.

Berdasarkan uraian di atas serta melihat beberapa permasalahan yang ada peneliti merasa perlu melakukan kebaruan penelitian dari penelitian-penelitian sebelumnya tentang pelatihan, persistensi dan kompetensi guru. Peneliti merasa tertarik untuk melakukan penelitian terkait dengan penggunaan metode pelatihan yang sesuai dengan kondisi saat ini dan bagaimana persistensi peserta pelatihan bisa berpengaruh terhadap kompetensi pedagogik yang dimiliki.

\section{METODOLOGI}

Metode penelitian yang dipergunakan adalah metode survey ex-post facto. Variabel penelitian terdiri dari: 1) variabel bebas (metode pelatihan), 2) variabel atribut atau moderator (persistensi), dan 3) variabel terikat (kompetensi pedagogik guru PAUD). Variabel bebas (metode pelatihan) yang dimaksud adalah motede pelatihan dalam jaringan (daring/online) dan metode pelatihan tatap muka. Variabel atribut atau moderator (persistensi) terdiri dari persistensi tinggi dan persistensi rendah.

Tabel 2. Gambaran Variabel Penelitian

\begin{tabular}{lll}
\hline \multicolumn{2}{c}{ Variabel Bebas } & Variabel Terikat \\
\hline Metode Pelatihan Dalam Jaringan & Persistensi Tinggi & $\mathrm{Y}_{1}$ \\
\cline { 2 - 3 } (daring/online) & Persistensi Rendah & $\mathrm{Y}_{2}$ \\
\hline Metode Pelatihan Tatap Muka (konvensional) & Persistensi Tinggi & $\mathrm{Y}_{3}$ \\
\cline { 2 - 3 } & Persistensi Rendah & $\mathrm{Y}_{4}$ \\
\hline
\end{tabular}

Desain yang digunakan dalam penelitian ini adalah desain factorial 2x2 (desain noneksperimental) karena variabel $\mathrm{X}_{2}$ atau B menunjukkan sebab dan akibat terhadap Y. Variabel $\mathrm{X}_{2}$ terbagi menjadi persistensi tinggi dan persistensi rendah, sedangkan variabel $\mathrm{X}_{1}$ atau $\mathrm{A}$ terbagi menjadi metode pelatihan dalam jaringan (daring/online) dan metode pelatihan tatap muka. Rancangan variabel sebagai berikut:

Tabel 3. Rancangan Desain Faktorial $2 \times 2$

\begin{tabular}{ccc}
\hline & \multicolumn{2}{c}{ Metode Pelatihan (A) } \\
\cline { 2 - 3 } & Metode Pelatihan Dalam & Metode Pelatihan \\
& Jaringan (Daring/Online) & Tatap Muka \\
\hline
\end{tabular}




\begin{tabular}{lccc}
\hline & & $\left(\mathrm{A}_{1}\right)$ & $\left(\mathrm{A}_{2}\right)$ \\
\hline \multirow{2}{*}{ Persistensi $(\mathrm{B})$} & Tinggi $\left(\mathrm{B}_{1}\right)$ & $\mathrm{A}_{1} \mathrm{~B}_{1}$ & $\mathrm{~A}_{2} \mathrm{~B}_{1}$ \\
\cline { 2 - 4 } & Rendah $\left(\mathrm{B}_{2}\right)$ & $\mathrm{A}_{1} \mathrm{~B}_{2}$ & $\mathrm{~A}_{2} \mathrm{~B}_{2}$ \\
\hline
\end{tabular}

Responden dalam penelitian ini sebanyak 595 orang. Dari 595 responden dipilih sampel sebanyak 239 orang guru PAUD yang telah mengikuti diklat dasar di Kota Administrasi Jakarta Timur secara cluster random sampling (Sugiyono, 2012).

Adapun teknik pengumpulan data yang digunakan adalah teknik non tes dengan instrumen berupa angket/kuisioner. Instrumen yang digunakan dibuat berdasarkan kerangka teoritik yang dibentuk dalam definisi konseptual dan definisi operasional yang kemudian disajikan dalam kisi-kisi instrumen. Instrumen yang dibuat kemudian diujicobakan untuk mengetahui kehandalan instrument sebagai alat pengumpulan data, dan selanjutnya dilakukan uji validitas untuk mengukur tingkat kebsahan suatu alat ukur dan uji reliabilitas untuk melihat konsistensi hasil pengukuran.

Penelitian ini adalah penelitian kuantitatif, sehingga analisis data yang dilakukan meliputi pengelolaan data dan penyajian data, perhitungan untuk mendeskripsikan data, dan pengujian hipotesis dengan menggunakan uji statistik.

\section{HASIL DAN PEMBAHASAN}

Pengujan hipotesis menggunakan teknik analisis varians dua jalur (ANAVA) desain treatmen by level $2 x 2$. Rangkuman hasil perhitungan analisis varians dua jalur disajikan pada tabel berikut :

Tabel 4. Rata-rata Kompetensi Pedagogik Guru PAUD pada Setiap Kelompok Perlakuan Descriptive Statistics

Dependent Variable: Kompetensi Pedagogik Guru PAUD (Y)

\begin{tabular}{|ll|r|r|r|}
\hline Metode Pelatihan (A) & Persistensi (B) & \multicolumn{1}{|c|}{ Mean } & Std. Deviation & \multicolumn{1}{|c|}{ N } \\
\hline A1 (Daring) & B1 (Presistensi Tinggi) & 30,48 & 2,373 & 33 \\
& B2 (Presistensi Rendah) & 27,73 & 2,440 & 33 \\
& Total & 29,11 & 2,763 & 66 \\
\hline A2 (Konvensional) & B1 (Presistensi Tinggi) & 26,06 & 2,555 & 31 \\
& B2 (Presistensi Rendah) & 29,55 & 2,188 & 31 \\
& Total & 27,81 & 2,941 & 62 \\
\hline Total & B1 (Presistensi Tinggi) & 28,34 & 3,306 & 64 \\
& B2 (Presistensi Rendah) & 28,61 & 2,479 & 64 \\
& Total & 28,48 & 2,913 & 128 \\
\hline
\end{tabular}

Tabel 5. Rangkuman Hasil Perhitungan Analisis Varians (ANAVA) Dua Jalur

Tests of Between-Subjects Effects

Dependent Variable: Kompetensi Pedagogik Guru PAUD (Y)

\begin{tabular}{|l|r|r|r|r|r|}
\hline \multicolumn{1}{|c|}{ Source } & $\begin{array}{r}\text { Type III Sum of } \\
\text { Squares }\end{array}$ & df & Mean Square & \multicolumn{1}{c|}{ F } & \multicolumn{1}{c|}{ Sig. } \\
\hline Corrected Model & $367,593 \mathrm{a}$ & 3 & 122,531 & 21,390 &, 000 \\
Intercept & 103547,870 & 1 & 103547,870 & 18075,856 &, 000 \\
A & 53,995 & 1 & 53,995 & 9,426 &, 003 \\
B & 4,216 & 1 & 4,216 &, 736 &, 393 \\
A B & 311,341 & 1 & 311,341 & 54,349 &, 000 \\
Error & 710,336 & 124 & 5,729 & & \\
Total & 104875,000 & 128 & & & \\
Corrected Total & 1077,930 & 127 & & & \\
\hline
\end{tabular}

a. $\mathrm{R}$ Squared $=, 341$ (Adjusted R Squared $=, 325$ ) 
Berdasarkan hasil analisis data yang telah dilakukan uji hipotesis, terdapat beberapa temuan yang akan dibahas diantaranya yaitu:

\section{Hipotesis Pertama}

Terdapat perbedaan kompetensi pedagogik guru PAUD antara guru yang mengikuti metode pelatihan dalam jaringan (daring/online) dan metode pelatihan tatap muka

Rata-rata Skor kompetensi pedagogik guru PAUD yang mengikuti metode pelatihan dalam jaringan (daring/online) $\left(\mathrm{A}_{1}\right)$ adalah 29,11 sedangkan rata-rata skor kompetensi pedagogik guru PAUD yang mengikuti metode pelatihan tatap muka $\left(\mathrm{A}_{2}\right)$ adalah 27,81 . Hasil perhitungan ANAVA dua jalur diperoleh $F_{\text {hitung }}$ untuk metode pelatihan sebesar 5,849 sedangkan $F_{\text {tabel }}(0,05 ; 1 ; 124)=3,92$ pada taraf nyata $\alpha=0,05$ dan nilai pvalue $<0,018(0,018<0,05)$. Oleh karena nilai rata-rata skor kompetensi pedagogik guru PAUD yang mengikuti metode pelatihan dalam jaringan (daring/online) lebih besar dari rata-rata skor kompetensi pedagogik guru PAUD yang mengikuti metode pelatihan tatap muka $\left(\mu \mathrm{A}_{1}>\mu \mathrm{A}_{2}\right)$ dan nilai ( $\mathrm{F}_{\text {hitung }}>\mathrm{F}_{\text {tabel }}$ ), maka $\left(\mathrm{H}_{0}\right)$ ditolak dan $\mathrm{H}_{1}$ diterima artinya bahwa terdapat perbedaan yang signifikan antara rata-rata skor kompetensi pedagogik guru PAUD yang mengikuti metode pelatihan dalam jaringan (daring/online) $\left(\mathrm{A}_{1}\right)$ dan rata-rata skor kompetensi pedagogik guru PAUD yang mengikuti metode pelatihan tatap muka $\left(\mathrm{A}_{2}\right)$. Dengan demikian hipotesis yang menyatakan terdapat perbedaan kompetensi pedagogik guru PAUD antara guru yang mengikuti metode pelatihan dalam jaringan (daring/online) dan metode pelatihan tatap muka adalah terbukti.

Hasil penelitian ini diperkuat dengan penelitian yang dilakukan oleh Claire McGuiness yang hasil penelitiannya menunjukkan bahwa pembelajaran berbasis elektronik terbukti menjadi pengalaman belajar bagi peserta didik karena memberikan kesempatan belajar menggunakan metode pembelajaran baru yang berbeda. Pelatihan secara elekronik (dalam jaringan) memiliki efek memperkuat pembelajaran tatap muka, dengan menyediakan objek pembelajaran yang dapat digunakan kembali yang dapat ditinjau kembali kapan saja dan dapat digunakan untuk memecahkan masalah dengan kemampuan masing-masing, meskipun beberapa masalah teknis terbukti mengganggu, namun pengalaman siswa secara keseluruhan adalah positif, menunjukkan bahwa struktur pembelajaran campuran yang diadopsi untuk kegiatan pelatihan ini efektif. Penelitian Claire ini sebagai bukti tentang efektivitas mode pembelajaran digital, bagaimana keterlibatan serta pembelajaran yang diberikan kepada peserta didik serta memberikan gagasan baru terkait dengan pelaksanaan pembelajaran secara online (McGuinness \& Fulton, 2019). Analisis relevansi penelitian dari Claire dengan penelitian ini adalah penggunaan metode pembelajaran digital atau penyampaian metode pelatihan pembelajaran menggunakan jaringan (daring/online) memberikan pandangan baru tentang pentingnya penggunaan teknologi sehingga guru memiliki kemampuan dalam berbagai penguasaan pendekatan, metode dan strategi untuk melaksanakan pembelajaran sehingga tidak terkesan monoton. Guru juga mampu mendayagunakan berbagai media pembelajaran dan mampu mengelola waktu dalam pembelajaran.

Penelitian lain yang mendukung adalah hasil penelitian dari Renee Crawford yang mengemukakakn keterampilan dan pengetahuan yang diperoleh setelah mengikuti kegiatan pembelajaran/pelatihan dengan metode blended learning oleh peserta didik dibuktikan dengan peserta memiliki pemikiran kreatif dan kritis, fleksibilitas dan kemampuan beradaptasi, serta mampu memecahankan masalah dengan cepat dan tepat (Crawford \& Jenkins, 2018). Analisis relevansi dengan hasil penelitian ini yaitu kompetensi pedagogik yang dimiliki guru dalam kemampuan mengelola waktu pembelajaran adalah penggunaan waktu secara efisien. Dengan guru memilih mengikuti pelatihan dengan metode dalam jaringan (daring/online), guru tidak harus meninggalkan lembaga dalam waktu yang lama untuk bisa mendapatkan wawasan dan pengalaman baru, namun guru tetap bisa melakukan kegiatan pembelajaran seperti biasa di lembaganya. 
Penelitian lainnya yang mendukung adalah hasil penelitian dari Mgnas Fernando dengan hasil penelitiannya yang mengemukakan materi pelajaran dan pelatihan terkait mengembangan kompetensi pedagogis adalah konsep penting dalam mendesain program pelatihan bagi guru. Sebagian besar program pelatihan guru dengan menggunakan TIK di negara-negara berkembang tidak memiliki kerangka teori yang kuat. Sementara itu sangat penting untuk menyatukan metode pengajaran dan pembelajaran dengan menggunakan TIK dalam pelaksanaan metode pelatihan. Oleh karena itu, untuk mendapatkan kompetensi pedagogis yang lebih baik, penggunaan TIK dalam pelatihan bagi guru harus digunakan. Metode kualitas yang terkait dengan pengajaran dan pelatihan guru sangat penting untuk mencapai hasil pembelajaran yang dipertahankan dalam standar kualitas internasional. Relevansi dengan hasil penelitian ini yaitu kemampuan yang terkait dengan kompetensi pedagogik guru dalam mendayagunakan media pembelajaran menjadi salah satu komponen penting dalam pendidikan untuk menunjang efektivitas dan efisiensi dkegiatan pembelajaran. Artinya dengan guru mampu menggunakan teknologi maka guru bisa menciptakan pembelajaran lebih menarik, pembelajaran lebih interaktif, lamanya waktu pembelajaran dapat dipersingkat, pembelajaran dapat diberikan kapan dan dimana saja, membangun sikap positif dalam memecahkan berbagai permasalahan serta metode pembelajaran lebih bervariasi.

Penelitian ini juga diperkuat penelitian yang dilakukan oleh Dyah Putri yang mengemukakan hasil penelitiannya bahwa keempat indikator pada kompetensi pedagogik (pemahaman pada peserta didik, perencanaan dan pelaksanaan pembelajaran, evaluasi hasil belajar, mengembangkan potensi yang dimiliki peserta didik) telah diterapkan dengan sangat baik oleh guru setelah mengikuti Pelatihan Guru Pembelajar Moda Daring (Safitri, Khaerudin, \& Ariani, 2018). Analisis relevansi penelitian tersebut dengan penelitian ini yaitu pemilihan metode pelatihan menjadi salah satu faktor penunjang efektifnya kegiatan pelatihan serta berkembangnya kompetensi pedagogik guru dalam menciptakan pembelajaran sebagai hasil dari pelatihan tersebut.

Selanjutnya Tintin Kartini mengemukakan tentang masih rendahnya kompetensi pendidik berdasarkan hasil rata-rata uji kompetensi guru tahun 2015 yang hanya sebesar 53,02. Untuk meningkatkan kompetensi pendidik PAUD, diklat berjenjang menjadi salah satu program yang dilaksanakan oleh pemerintah. Salah satu inovasi dalam penyelenggaraan diklat berjenjang yaitu dengan moda dalam jaringan (daring). Strategi pembelajaran diklat daring berbeda dengan diklat konvensional dan berimplikasi pada personil yang terlibat (Kartini \& Rusman, 2018).

Berdasarkan pembahasan di atas maka dapat disimpulkan bahwa hasil penelitian ini relevan dengan penelitian yang telah ada. Perbedaan yang signifikan antara metode pelatihan dalam jaringan (daring/online) dengan metode pelatihan tatap muka/konvensional terhadap kompetensi pedagogik guru PAUD adalah terbukti. Dengan demikian metode pelatihan dalam jaringan (daring/online) mempengaruhi kompetensi pedagogik guru PAUD dibandingkan dengan guru PAUD yang mengikuti pembelajaran dengan metode tatap muka/konvensional. Dengan penggunaan media berbasis teknologi membuat guru lebih cepat dalam mendapatkan informasi dan wawasan, sehingga berdampak positif dalam keseharian guru mulai dari merencanakan kegiatan pembelajaran bagi peserta didiknya hingga melakukan evaluasi dan penilaian.

\section{Hipotesis Kedua \\ Pengaruh Interaksi Metode Pelatihan dan Persistensi terhadap Kompetensi Pedagogik Guru PAUD}

Hasil perhitungan ANAVA bahwa $F_{\text {hitung }}$ untuk faktor interaksi yaitu 54,349 lebih besar daripada $F_{\text {tabel }}$ yaitu 3,92 pada taraf nyata $a=0.05$, dengan demikian tolah $\mathrm{H}_{0}$ dan terima $\mathrm{H}_{1}$ dan dapat disimpulkan terdapat pengaruh interaksi antara metode pelatihan dan persistensi terhadap skor kompetensi pedagogik guru PAUD. Bentuk grafik interaksi antara 
metode pelatihan dan persistensi terhadap skor kompetensi pedagogik guru PAUD disajikan pada gambar berikut:

\section{Gambar 1. Grafik Interaksi Metode Pelatihan dan Persistensi terhadap Kompetensi Pedagogik Guru PAUD}

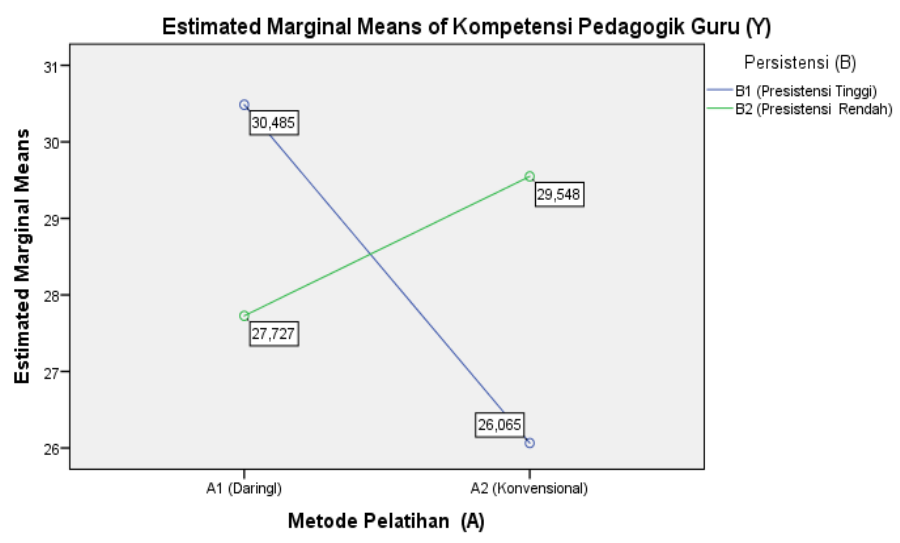

Hasil pengujian ini menggambarkan bahwa terdapat interaksi yaitu pengaruh yang signifikan antara metode pelatihan dan persistensi terhadap kompetensi pedagogik guru PAUD. Beberapa penelitian relevan lainnya yang menunjukkan dintaranya adalah pendapat dari Cathrine yang mengemukakan cara mendidik guru di zaman millennium ini dengan memberikan pelatihan dalam penguasaan teknologi, informasi dan komunikasi (TIK) serta bagaimana meningkatkan kompetensi guru dalam penguasaan teknologi dan hasilnya adalah guru senang mengikuti kegiatan yang menggunakan fasilitas teknologi meskipun kendala yang harus dihadapi adalah pemenuhan sarana teknologi itu sendiri (Tomte, 2013). Pendapat lain disampaikan dari hasil penelitian Mugenyi yang menyampaikan hasil penelitiannya bahwa adanya dalam pembelajaran blended learning dengan persistensi yang tinggi mendorong evektifitas dalam kegiatan pembelajaran. Selain itu tidak ada perbedaan antara pembelajar laki-laki dan perempuan maupun kelompok usia dalam pembelajaran blended learning (Kintu, Zhu, \& Kagambe, 2017).

Ayu Lestari memaparkan hasil penelitiannya dimana perlu menanamkan nilai-nilai organisasi kepada semua warga sekolah sejak dini. Kepala sekolah sebagai atasan langsung guru di sekolah hendaknya secara aktif memperhatikan persistensi yang dimiliki guru dalam bekerja untuk mengupayakan pencegahan counterproductive behaviour guru dalam bekerja. Peningkatan persistensi guru dipengaruhi kemampuan emosional yang baik dan kompetensi pedagogik guru dalam berkomunikasi secara efektif, empatik dan satun kepada semua pihak. Diperlukan juga ketegasan, konsisten, komitmen serta teladan dari Kepala Sekolah (Lestari, 2015). Sama halnya dengan penelitian ini bahwa menjadi seorang guru yang professional harus memiliki kompetensi pedagogik yang baik dimana peningkatan kompetensi dapat dilakukan dengan cara mengikuti berbagai pendidikan dan pelatihan serta memiliki persistensi yang tinggi. Selain itu penggunaan metode pelatihan yang sesuai dengan perkembangan zaman dan persistensi yang tinggi akan memberikan dampak positif bagi peningkatan kompetensi pedagogik guru PAUD, dimana menjadi pribadi yang peduli dengan dunia maya, memiliki rasa ingin tahu yang tinggi dengan kemauan memanfaatkan TIK, serta dapat dengan mudah menyelesaikan lebih dari satu pekerjaan dalam satu waktu. Berdasarkan pembahasan ini, maka dapat disimpulkan bahwa hasil penelitian ini relevan dengan penelitian yang telah ada. Pengaruh yang signifikan anatara metode pelatihan dan persistensi terhadap kompetensi pedagogik guru PAUD adalah terbukti.

\section{Hipotesis Ketiga}

Terdapat perbedaan kompetensi pedagogik guru PAUD antara guru yang mengikuti pelatihan metode dalam jaringan (daring/online) dengan persistensi tinggi dan guru yang mengikuti pelatihan metode tatap muka dengan persistensi tinggi 
Skor rata-rata skor kompetensi pedagogik guru PAUD yang mengikuti metode pelatihan dalam jaringan (daring/online) dengan persistensi tinggi $\left(\mathrm{A}_{1} \mathrm{~B}_{1}\right)$ adalah 30,48 sedangkan skor rata-rata skor kompetensi pedagogik guru PAUD yang mengikuti metode pelatihan tatap muka dengan persistensi tinggi $\left(\mathrm{A}_{2} \mathrm{~B}_{1}\right)$ adalah 26,06 dan Uji Tuckey menunjukkan perbedaan rata-rata skor antara guru PAUD yang mengikuti metode pelatihan dalam jaringan (daring/online) dengan persistensi tinggi $\left(\mathrm{A}_{1} \mathrm{~B}_{1}\right)$ dan guru PAUD yang mengikuti metode pelatihan tatap muka dengan presistensi tinggi $\left(\mathrm{A}_{2} \mathrm{~B}_{1}\right)$ sebesar 4,42 dan nilai p-value (Sig) sebesar 0,000, oleh karena nilai p-value lebih kecil dari nilai alpha $(0,000<$ $0,05)$ dengan demikian dapat disimpulkan $\mathrm{H}_{0}$ ditolak dan $\mathrm{H}_{1}$ diterima yang berarti bahwa terdapat perbedaan kompetensi pedagogik guru PAUD yang signifikan antara guru yang mengikuti pelatihan metode dalam jaringan (daring/online) dengan persistensi tinggi dan guru yang mengikuti pelatihan metode tatap muka dengan persistensi tinggi.

Hasil penelitian ini menggambarkan bahwa terdapat perbedaan data kompetensi pedagogik guru PAUD antara metode pelatihan dalam jaringan (daring/online) dan persistensi tinggi dengan kompetensi pedagogik guru PAUD dengan metode pelatihan tatap muka yang sama-sama persistensi tinggi. Akan tetapi dalam hal ini juga ditemukan kontribusi persistensi jelas berpengaruh terhadap kompetensi pedagogik guru PAUD.

Hasil rerata skor dan pengujian Tuckey metode pelatihan dalam jaringan (daring/online) dan persistensi tinggi terhadap kompetensi pedagogik guru PAUD diperkuat dengan hasil penelitian Mareike Kunter yang menyatakan motivasi yang di dalamnya terdapat bagian tentang persistensi/ketekunan menjadi sangat diperlukan bagi guru dalam jangka panjang untuk menentukan perkembangan profesi mereka. Dengan adanya persistensi yang tinggi menunjukkan bahwa guru memiliki motivasi dari dalam diri untuk bisa menciptakan pembelajaran yang menyenangkan (Kunter et al., 2013). Sedangkan Marian menyatakan bahwa implementasi dari pelatihan menggunakan metode blended learning (pelatihan campuran antara tatap muka dengan online) sebagai salah satu inovasi kegiatan pelatihan bisa diberikan kepada guru (Byrka, 2017). Pradeep Kumar mengatakan dalam penelitiannya bahwa dalam perkembangan zaman saat ini, guru-guru membutuhkan jenis pelatihan yang bisa dilakukan secara massal, tidak adanya kesenjangan (bisa diikuti oleh siapa saja), nyaman dan mudah dilakukan dimana saja. Salah satu pelatihan yang bisa dilakukan yaitu dengan metode OER (The Open Educational Resources) atau pelatihan secara online (Misra, 2014). Ketiga penelitian sejalan dengan penelitian ini yaitu metode pelatihan daring lebih efektif dalam meningkatkan kompetensi pedagogik guru PAUD yang juga diikuti dengan memiliki persistensi tinggi.

Mieke dalam penelitiannya menyatakan bahwa persistensi atau ketekunan merujuk pada kuantitas waktu yang digunakan oleh seseorang dalam menyelesaikan sebuha pekerjaan. Seseorang yang memiliki persistensi tinggi bisa menyelesaikan tugas dengan tepat waktu dan dapat meningkatkan kemampuannya dalam menerapkan hasil belajarnya. Adapun hubungan antara persistensi dengan hasil belajar didasarkan pada komitmen seseorang untuk mendapatkan hasil yang baik seseorang akan berusaha fokus dalam menyelesaikan pekerjaannya (Miarsyah, Putrawan, \& Hermasianti, 2016). Penelitian tersebut mendukung penelitian ini, yaitu kompetensi pedagogik guru PAUD lebih tinggi bila mengikuti metode pelatihan dalam jaringan (daring/online) dan memiliki persistensi tinggi.

Berdasarkan pembahasan di atas, maka dapat disimpulkan perbedaan antara guru yang mengikuti metode pelatihan dalam jaringan (daring/online) dan persistensi tinggi dengan metode pelatihan tatap muka dan persistensi tinggi.

\section{Hipotesis Keempat}

Terdapat perbedaan kompetensi pedagogik guru PAUD antara guru yang mengikuti pelatihan metode daring dengan persistensi rendah dan guru yang mengikuti pelatihan metode tatap muka dengan persistensi rendah 
Skor rata-rata kompetensi pedagogik guru PAUD yang mengikuti metode pelatihan dalam jaringan (daring/online) dengan persistensi rendah $\left(\mathrm{A}_{1} \mathrm{~B}_{2}\right)$ adalah 27,73 sedangkan skor rata-rata kompetensi pedagogik guru PAUD yang mengikuti metode pelatihan tatap muka dengan persistensi rendah $\left(\mathrm{A}_{2} \mathrm{~B}_{2}\right)$ adalah 29,55 dan Uji Tuckey menunjukkan perbedaan rata-rata skor antara guru PAUD yang mengikuti metode pelatihan dalam jaringan (daring/online) dengan persistensi rendah $\left(\mathrm{A}_{1} \mathrm{~B}_{2}\right)$ dan guru PAUD yang mengikuti metode pelatihan tatap muka dengan persistensi rendah $\left(\mathrm{A}_{2} \mathrm{~B}_{2}\right)$ sebesar $-1,82$ dan nilai p-value (Sig) sebesar 0,015, oleh karena nilai p-value lebih kecil dari nilai alpha $(0,015<0,05)$ dengan demikian dapat disimpulkan $\mathrm{H}_{0}$ ditolak dan $\mathrm{H}_{1}$ diterima yang berarti bahwa terdapat perbedaan yang signifikan antara kompetensi pedagogik guru PAUD antara guru yang mengikuti pelatihan metode daring dengan persistensi rendah dan guru yang mengikuti pelatihan metode tatap muka dengan persistensi rendah, sehingga untuk guru PAUD dengan persistensi rendah, maka kompetensi pedagogik guru lebih tinggi bila mengikuti metode pelatihan tatap muka. Rangkuman hasil Uji Tuckey disajikan pada tabel berikut:

Tabel 6. Rangkuman Uji Tuckey Skor Kompetensi Pedagogik Guru PAUD yang Mengikuti Metode Pelatihan Dalam Jaringan (Daring/Online) dan Metode Pelatihan Tatap Muka dengan Persistensi Rendah

Multiple Comparisons

Dependent Variable: Kompetensi Pedagogik Guru PAUD (Y)

Tukey HSD

\begin{tabular}{|c|c|c|c|c|c|c|}
\hline \multirow[b]{2}{*}{ (I) $\mathrm{AXB}$} & \multirow[b]{2}{*}{ (J) $\mathrm{AXB}$} & \multirow{2}{*}{$\begin{array}{c}\text { Mean } \\
\text { Difference } \\
\text { (I-J) }\end{array}$} & \multirow[b]{2}{*}{ Std. Error } & \multirow[b]{2}{*}{ Sig. } & \multicolumn{2}{|c|}{ 95\% Confidence Interval } \\
\hline & & & & & $\begin{array}{l}\text { Lower } \\
\text { Bound }\end{array}$ & $\begin{array}{l}\text { Upper } \\
\text { Bound }\end{array}$ \\
\hline \multirow{3}{*}{$\begin{array}{l}\text { A1B1 } \\
\text { (MPD - PST) }\end{array}$} & A1B2 (MPD- PSR) & $2,76^{*}$ &, 589 & ,000 & 1,22 & 4,29 \\
\hline & A2B1 (MPT - PST) & $4,42^{*}$ &, 599 & ,000 & 2,86 & 5,98 \\
\hline & A2B2 (MPT - PSR) & ,94 &, 599 & ,403 &,- 62 & 2,50 \\
\hline \multirow{3}{*}{$\begin{array}{l}\text { A1B2 } \\
\text { (MPD- PSR) }\end{array}$} & A1B1 (MPD - PST) & $-2,76^{*}$ & ,589 & ,000 & $-4,29$ & $-1,22$ \\
\hline & A2B1 (MPT - PST) & $1,66^{*}$ &, 599 & ,032 & 10 & 3,22 \\
\hline & A2B2 (MPT - PSR) & $-1,82^{*}$ & ,599 & ,015 & $-3,38$ &,- 26 \\
\hline \multirow{3}{*}{$\begin{array}{l}\text { A2B1 } \\
\text { (MPT - PST) }\end{array}$} & A1B1 (MPD - PST) & $-4,42^{*}$ &, 599 & ,000 & $-5,98$ & $-2,86$ \\
\hline & A1B2 (MPD- PSR) & $-1,66^{*}$ &, 599 & ,032 & $-3,22$ &,- 10 \\
\hline & A2B2 (MPT - PSR) & $-3,48^{*}$ & 608 & , 000 & $-5,07$ & $-1,90$ \\
\hline \multirow{3}{*}{$\begin{array}{l}\text { A2B2 } \\
\text { (MPT - PSR) }\end{array}$} & A1B1 (MPD - PST) &,- 94 &, 599 & 403 & $-2,50$ & ,62 \\
\hline & A1B2 (MPD- PSR) & $1,82^{*}$ &, 599 & ,015 &, 26 & 3,38 \\
\hline & A2B1 (MPT - PST) & $3,48^{*}$ & 608 &, 000 & 1,90 & 5,07 \\
\hline
\end{tabular}

Based on observed means.

The error term is Mean Square(Error) $=5,729$.

*. The mean difference is significant at the ,05 level.

Hasil penelitian ini menunjukkan bahwa metode pelatihan dalam jaringan (daring/online) dan persistensi rendah lebih rendah daripada metode pelatihan tatap muka dan persistensi rendah.

Berdasarkan rerata skor dan pengujian Tuckey metode pelatihan tatap muka dan persistensi rendah terhadap kompetensi pedagogik guru PAUD diperjelas dari hasil penelitian Laksmi Dewi yang dalam penelitiannya mengatakan pelatihan yang berhasil 
adalah pelatihan yang dapat memberikan nilai tambah pada pengetahuan, sikap dan keterampilan peserta. Pelatihan yang baik adalah pelatihan yang sesuai dengan kebutuhan peserta dan hasilnya dapat diterapkan di dunia kerja peserta. Pelatihan PAIKEM yang telah dilaksanakan berhasil memberikan sumbangan bagi peningkatan kompetensi pedagogik para peserta (Dewi \& Suhardini, 2014). Analisis relevansi hasil penelitian tersebut dengan penelitian ini yaitu guru PAUD dengan persistensi rendah kompetensi pedagogik guru PAUD akan lebih tinggi bila mengikuti metode pelatihan tatap muka. Secara ringkas dapat disimpulkan bahwa terdapat perbedaan kompetensi pedagogik antara guru PAUD yang mengikuti metode pelatihan dalam jaringan (daring/online) dan persistensi rendah dengan metode pelatihan tatap muka dan persistensi rendah.

\section{SIMPULAN}

Terdapat pengaruh yang signifikan antara metode pelatihan dan persistensi terhadap kompetensi pedagogik guru PAUD. Metode pelatihan dalam jaringan (daring/online) mempengaruhi kompetensi pedagogik guru PAUD dibandingkan dengan guru PAUD yang mengikuti pembelajaran dengan metode tatap muka/konvensional. Dengan penggunaan media berbasis teknologi baik saat mengikuti kegiatan seperti diklat maupun saat sehari-hari guru mengajar serta dengan memiliki persistensi/ketekunan/kegigihan dalam mendapatkan sesuatu membuat guru lebih cepat dalam mendapatkan informasi, wawasan dan pengetahuan baru, sehingga berdampak positif dalam keseharian guru mulai dari merencanakan kegiatan pembelajaran bagi peserta didiknya hingga melakukan evaluasi dan penilaian.

\section{UCAPAN TERIMAKASIH}

Peneliti mengucapkan terimakasih kepada Pusat Pelatihan Pengembangan Pendidikan Anak Usia Dini dan Pendidikan Masyarakat (P3PNFI) Provinsi Daerah Khusus Ibukota Jakarta dan PP PAUD dan Dikmas Jawa Barat sebagai tempat observasi awal dalam pengambilan data peserta diklat dasar bagi guru PAUD, Dinas Pendidikan Kabupaten Bogor sebagai tempat ujicoba penelitian, serta Suku Dinas Pendidikan Wilayah I dan II Kota Administrasi Jakarta Timur atas izinnya untuk melakukan penelitian dengan responden guru-guru PAUD.

\section{DAFTAR PUSTAKA}

Apelgren, K., \& Giertz, B. (2010). Pedagogical Competence - A Key To Pedagogical Development And Quality In Higher Education. A Swedish Perspective on Pedagogical Competence, 1-138.

Apriyanti, H. (2017). Pemahaman Guru Pendidikan Anak Usia Dini Terhadap Perencanaan Pembelajaran Tematik. Jurnal Obsesi: Jurnal Pendidikan Anak Usia Dini, 1(2), 111. https://doi.org/10.31004/obsesi.v1i2.22

Arianto, D. A. N., \& Istikomah. (2018). Pengaruh Kontribusi Pendidikan, Pelatihan dan Komunikasi Organisasi Terhadap Kinerja Guru (Studi di SMP Negeri 1 Tahunan Jepara). Media Ekonomi Dan Manajemen, 33(2), 149-163.

Bilfaqih, Y., \& Qomarudin, M. N. (2015). Esensi Pengembangan Pembelajaran Daring - Panduan Berstandar Pengembangan Pembelajaran Daring untuk Pendidikan dan Pelatihan. Yogyakarta: Deepublish.

Byrka, M. F. (2017). Blended Learning Strategy In Teacher Training Programs. Information Technologies and Learning Tools, 62, 216-224.

Colquitt, J. A., Lepine, J. A., \& Wesson, M. J. (2009). Organizational Behavior: Improving Performance and Commitment in the Workplace. New York: McGrawHill/Irwin.

Crawford, R., \& Jenkins, L. E. (2018). Making pedagogy tangible: Developing skills and knowledge using a team teaching and blended learning approach. Australian Journal 
of Teacher Education, 43(1), 127-142. https:/ / doi.org/10.14221/ajte.2018v43n1.8

Dewi, L., \& Suhardini, A. D. (2014). Peningkatan Kompetensi Pedagogik Guru Melalui Pelatihan Paikem (Pelatihan Pada Guru Mi Dan Mts Di Kabupaten Cianjur). Edutech, 13(3), 409. https:// doi.org/10.17509/edutech.v13i3.3094

Dit.Bin. GTK PAUD dan Dikmas, T. (2018). Pedoman Diklat Guru Pendamping Muda (Diklat Berjenjang Tingkat Dasar). Jakarta: Direktorat Jenderal Guru dan Tenaga Kependidikan.

Donovan, \& Umar, K. (2010). Perilaku Organisasi. Bandung: Pustaka Setia.

Febriana, R. (2016). Identifikasi Komponen Model Pelatihan Pedagogi untuk Meningkatkan Profesionalitas Calon Guru Kejuruan. Jurnal Pendidikan Teknologi Dan Kejuruan, 23(1), 79. https://doi.org/10.21831/jptk.v23i1.9487

Guerriero, S. (2013). Teachers' Pedagogical Knowledge and the Teaching Profession: Background Report and Project Objectives.

Kartini, T., \& Rusman. (2018). Studi Evaluatif Kurikulum Diklat Berjenjang Tingkat Dasar Dalam Jaringan Terhadap Peningkatan Kompetensi Pendidik PAUD. Pendidikan Luar Sekolah, 2(September), 74-86.

Kintu, M. J., Zhu, C., \& Kagambe, E. (2017). Blended Learning Effectiveness: The Relationship Between Student Characteristics, Design Features and Outcomes. International Journal of Educational Technology in Higher Education, 14(1). https:// doi.org/10.1186/s41239-017-0043-4

Kunter, M., Klusmann, U., Baumert, J., Richter, D., Voss, T., \& Hachfeld, A. (2013). Professional competence of teachers: Effects on instructional quality and student development. Journal of Educational Psychology, 105(3), 805-820. https:// doi.org/10.1037/a0032583

Lestari, A. (2015). Pengaruh Kemampuan Emosional dan Persistensi terhadap Counterproductive Behavior Guru SD Negeri Kecamatan Belitang Madang Raya Kota Palembang SumSel. Universitas Negeri Jakarta.

Maiza, Z., \& Nurhafizah, N. (2019). Pengembangan Keprofesian Berkelanjutan dalam Meningkatkan Profesionalisme Guru Pendidikan Anak Usia Dini. Jurnal Obsesi: Jurnal Pendidikan Anak Usia Dini, 3(2), 356. https:/ / doi.org/10.31004/obsesi.v3i2.196

McGuinness, C., \& Fulton, C. (2019). DIGITAL LITERACY IN HIGHER EDUCATION:ACASE STUDY OF STUDENT ENGAGEMENT WITH E-TUTORIALS USING BLENDED LEARNING. Jurnal of Information Technology Education : Innovation in Practice, 18(2), 1-28.

Miarsyah, M., Putrawan, I. M., \& Hermasianti, D. (2016). Hubungan Antara Ketekunan (Persistence) dengan Hasil Belajar Biologi: Studi Kasus Korelasi Terhadap Siswa Kelas X MIA dia SMA Negeri 102 Jakarta. Biosfer: Jurnal Pendidikan Biologi, 9. https:// doi.org/10.1017/CBO9781107415324.004

Misra, P. K. (2014). Online training of teachers using OER: Promises and potential strategies. Open Praxis, 6(4), 375-385. https://doi.org/10.5944/openpraxis.6.4.155

Panev, M. V., \& Barakoska, A. (2015). The Need of Strengthening The Pedagogical Competencies in Teaching from The English Teachers' Perspective. International Journal of Cognitive Research in Science, Engineering and Education, 3(1), 43-50.

Peterson, C., \& Seligman, M. E. . (2004). Character Strengths and Virtues. Values in Action Institute.

PP PAUD dan Dikmas, T. (2018). Panduan Penyelenggaraan Diklat Berjenjang Tingkat Dasar Bagi Guru PAUD Dalam Jaringan. Jawa Barat: Pusat Pengembangan Pendidikan Anak Usia Dini dan Pendidikan Masyarakat.

Puteri, T. K., \& Tj, H. W. (2016). Pengaruh Pendidikan dan Pelatihan kerja serta Lingkungan Kerja Terhadap Kinerja Karyawan PT. Inplasco Prima Surya. 16(1).

Rumengan, I. M., Lumenta, A. S. M., \& Paturusi, S. D. E. (2019). Pembelajaran Daring Pendidikan dan Pelatihan Aparatur Sipil Negara Badan Pengembangan Sumber Daya 
DOI: $10.31004 /$ obsesi.v4i2.440

Manusia Papua Barat. Jurnal Teknik Informatika, 14(3), 303-312. https:// doi.org/10.35793/jti.14.3.2019.24147

Safitri, D. P., Khaerudin, \& Ariani, D. (2018). Evaluasi Kompetensi Pedagogik Guru Pasca Pelatihan Guru Pembelajar Moda Daring. 1(159), 33-36.

Sakti, T. K., Hairunisya, N., \& Sujai, I. S. (2019). Pengaruh Kompetensi Pedagogik Guru dan Gaya Belajar Siswa Terhadap Prestasi Belajar Siswa pada Mata Pelajaran IPS. Jurnal Pendidikan Ilmu Sosial, 28(1), 53-60.

Suciu, A. I., \& Mata, L. (2011). Pedagogical Competences - The Key to Efficient Education. 3(2), 411-423.

Sugiyono. (2012). Metode Penelitian Pendidikan Pendekatan Kuantitatif, Kualitatif, dan RED. Bandung: Alfabeta.

Tomte, C. E. (2013). Educating teachers for the new millennium? Nordic Journal of Digital Literacy, 2013(1), 74-89.

Zamista, A. A. (2018). Increasing Persistence of Collage Students in Science Technology Engineering and Mathematic (STEM). Curricula, 3(1), 22-31. https:// doi.org/10.22216/jcc.2018.v3i1.1308 